\title{
Value and Price of Russian Business: The Entity, the Relationship and Impact of Financial Indicators
}

\author{
Kosorukova Irina*, Plyasova Svetlana, Prokimnov Nikolay and Rodin Alexander
}

Moscow University of Industry and Finance «Synergy»125190, Moscow, Leningradsky pr-t, 80G, Russia

\begin{abstract}
Topicality: In the article the authors analyze the relationship between the book and market value and the price (level of capitalization) of the business, and also analyze the nature of the relationship of these indicators with the traditional financial ratios. The purpose of the article is to determine the state of these relations in the modern economy of Russia.

Practical Usefulness: Determination of materiality influence of financial coefficients which used in traditional financial analysis on value and price of business that gives the chance of forecasting of development and decision-making within management of business 'value, and also more effective investment of means in securities.

Novelty: In modern Russian economic conditions, only part of the traditional financial ratios has an impact on the prices and business value. The analysis presented in the article indicates the feasibility of forming such a system of indicators, which is more informative in terms of their use for the implementation of value-based analysis and approach for decisionmaking in the organization.
\end{abstract}

Keywords: Value business, price business, financial indicators, statistical analysis.

\section{INTRODUCTION}

The problem of valuation was one of the central problems of economic science and excited scientistseconomists at all times, since merkantilists and classics.

"The purposes and motives of activity of economic entities are determined, options and allocation of resources and revenues are selected, the process of market exchange operates on the basis of the theory of value" [Rumyantseva, 2006].

Classics of political economy: A. Smith, W. Petty, D. Ricardo expressed their understanding of the value, Marx was engaged with this problem, like many other representatives of different schools.

It is known, the development of attitudes regarding the value originated in the writings of William Petty, Adam Smith and then David Ricardo developed understanding of the value under the labor theory. A. Smith conducts the division of value to the customer and exchange. Karl Marx considers in detail the problem of the labor theory of value in "Capital".

The Austrian school (K. Menger, E. Berm-Baverk and others) with the marginal utility theory was the alternative position of the labor theory of value. Here the value of goods is determined by the "marginal

*Address correspondence to this author at the Moscow University of Industry and Finance "Synergy" 125190, Moscow, Leningradsky pr-t, 80G, Russia; Tel: +7 (903) 722 9387; E-mail: ikosorukova@synergy.ru utility" on the basis of subjective evaluations of human needs. The rarity of the goods is the factor value.

In the modern Economics labor theory of value and marginal utility theory complement each other. Alfred Marshall, founder of the Cambridge neoclassical school brought together the theory of marginal utility (marginalism) and a theory of production value (classical political economy).

It is known, the law of value is the production and exchange of commodities take place on the basis of their value, the amount of which is determined by the socially necessary labor inputs.

He expresses the relation of commodity producers: the connection between the public labor, value and price of the goods.

The law of value is to make the private labor in the public work by mapping through a single measure socially necessary labor costs and the equivalence of the exchange between producers by expression and measuring costs through cost and recovery of proceeds from sales.

In economic literature, the mechanism of its manifestations consists in the following functions:

- accounting and estimating (market makes their cost estimating and accounting, through the price mechanism. In value terms are taken into account macroeconomic (gross national product, national income) and microeconomic (income), assessment of efficiency, rate of return, capital 
productivity, consumption of materials, labor productivity, and evaluation of resources, etc.,));

- regulatory (price fluctuation around the value leads to an influx or outflow of capital and labor, therefore, to increase or decrease the volume of production - growth or reduction of supply decrease or increase prices. Price fluctuations around the values govern the scale of production of various goods);

- $\quad$ stimulating (only those entities may recover costs and earn profits when the individual costs equal to or less socially necessary labor costs, this is possible on the basis of achievements of scientific and technical progress and growth of personnel qualification);

- differentiating (as a result of differentiation of subjects of economic stratification of the population and social stratification).

The labor cost in the sphere of production forms the basis of the market prices, but from the production the product of labor goes into the sphere of the economic relations, where competition acts, the law of supply and demand, causing the deviation of price from value. It is generally accepted that for a long period of time demand and supply are balanced and fluctuating around cost levels, and market prices are close to market value.

The difference between price and value creates problems of the analysis of factors affecting the value of the different property. This problem is very important in business valuation. In fact, equity prices on the stock market are so different from their fundamental value, that the results of the market approach in business valuation are considered in last turn as the most unreliable. The root of the problem here is based on the assumption of market ineffectiveness [Damodaran, 2002]. The problem of the measurement of the business cost and its analysis appears.

In developed countries value-based management is included in the system of Value Based Management management aimed at the value creation, management and valuation.

At present top corporations it is not a question of the importance of management business value. VBM, is one of the most productive modern concepts of management, examines the increased value of the business as the main goal of the company [Copeland, Koller, Murrin, 2005].

As practice shows, the rising in the value for the owners is not contrary to the long-term interests of other interested sides. Successfully operating organizations create relatively more value for all related agents - consumers, employees, the state and capital provider and by many other reasons [Kozyr, 2004].

First, the business value is one of the best known measures of enterprise effectiveness. Secondly, the owners of the business are the only participants of the organization, who taking care about maximizing their welfare, contribute to greater prosperity for all others stakeholders. This thesis currently, is the most applicable, and is confirmed by the practice of Western companies, in contrast to the Russian practice, where different groups of owners often pursue different goals, which do not create, but reduce the cost. And, finally, companies operating inefficiently will face with the diversion of capital to the competitors.

The problem of correlation of price and value is often raised in a modern special literature [Damodaran, 2002]. Authors often identify the value and the price in the modern research, which is incorrect from the point of view of economic theory [Varfolomeev, 2011; Staryuk,2008]. To formulate the meaning of the value briefly, this is a category which reflects the measure of the usefulness of things, labor cost and relative rarity of things and the price is the actual monetary amount paid or expected to be paid in the course of the transaction. In the analysis of the business value, the value of market capitalization of the company, i.e. shares prices, formed on the stock market is often used.

\section{THE MAIN PART}

In this paper the author would like to analyze the relationship between value and price of the business, as well as the degree of influence on them of some financial indicators and, first, to build an econometric model of dependence in modern conditions; secondly, to define the relationship of price and value by correlating financial ratios traditionaly used in financial analysis of companies.

Research of the value and price have already been conducted on the Russian market according to the data for 2002-2003 The results of this study [Bukhvalov, 2012], as well as other-similar studies show the presence of a fairly strong correlation between the market price and the business value. 
The author of this article set a task to analyze the closeness of ties between the price and the business value, formed using different indicators and calculation methods. Value calculation was carried out using Gordon's model [Copeland, Koller, Murrin, 2005], where the value of the cash flow was formed by different ways.

Such approach to the formation of indicators is due to a desire to understand assessment procedures conducted by the appraiser when calculating the market value of the business in an income capitalization approach are accurate. Appraiser, evaluating the business value uses the estimated cash flow. We used two types of cash flow for business valuation. These figures of the value were used to examine their correlation with the level of capitalization of the company. In addition, the results of book value of equity were used as well as for the analysis of the levels of capitalization.

The authors of the work carried out an analysis of indicators described according to the summary data of work 240 of Russian companies in 2011. Initial data for the analysis were taken from the system of comprehensive information disclosure NAUFOR about issuers (www.skrin.ru).

As it has already noted, the relationship between the level of capitalization of these companies and their value were examined in the analysis. Meanwhile, the indicator value was determined according to balance sheet and the income approach using cash flow, calculated in several ways:

1. Operating cash flow, from cash flow statement;

2. Total cash flow (CFFE) from cash flow statement.

3. Book value from financial statement report in Russian accounting standards (RAS) and IFRS

We analyzed the quantitative and qualitative realtion of market price and business value. We have used the tools of statistical analysis in Excel (2011) and SPSS software package (2012-2016). In particular, it is financed from the calculation of the linear coefficient of pair correlation (Correlation) and ranking of rows to calculate the rank correlation coefficient ("Rank and percentile"). The regression analyze Regression was deployed for finding the coefficients of linear regression equation and check its adequacy in case of detection of a significant correlation between indexes.
The results of the verification of the existence of relationships between the indicators are presented in Table 1. The table uses the following notations:

$\mathrm{n}$ - sample size (number of enterprises surveyed),

$r$ - Pearson correlation coefficient,

$\rho$ - Spearman correlation coefficient.

For the revealed cases of essential correlation communication between parameters the equations of linear regress have been constructed. In Table 2 the received factors of the equations and parameter $r^{2}$ the value of the coefficient of determination.

As follows from the results shown in Table 2, concerning majority of the constructed equations with probability of $95 \%$ it is possible to approve, that it is adequate and is capable with the specified reliability to predict experimental results.

Results of the analysis of communication between price and value received in the different ways, specifies that quantitative and qualitative relation between analyzed parameters is presented in most cases. In most cases there is an opportunity of construction regression dependences between analyzed parameters. Absence of quantitative dependence is observed between price and value received from the operating cash flow in 2011 and 2016, and between the price and the value received from the total cash flow in 2012-2016, the best results are found out between price and book value of equity according to IFRS in 2011 and the price and value received from the operating cash flow in 2013 and 2014. There is no quantitative dependence in all parameters in 2012.

The equations of regress specify the presence of direct linear dependence between analyzed parameters. The highest level of factor of determination at the equation describing influence of size of book value of own capital according to IFRS on a level of capitalization in 2011, impact of the value of operating cash flow on the level of capitalization in 2013-2015. Models can be used for forecasting size of a level of capitalization of the companies. It is interesting, that descriptive properties of similar one-factorial model in 2002-2003 $\left(r^{2}=0,603[8, p .176]\right)$, have practically coincided with properties of the model received by us in $2011\left(r^{2}=0,57\right)$. 


\begin{tabular}{|c|c|c|c|c|c|}
\hline \multicolumn{2}{|c|}{ 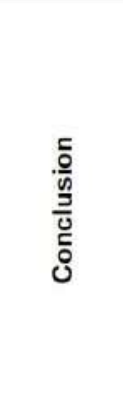 } & 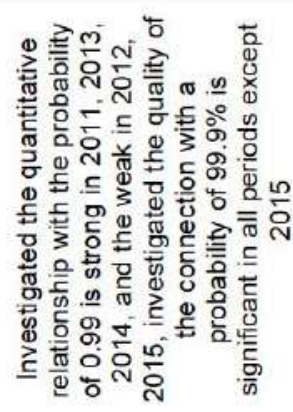 & 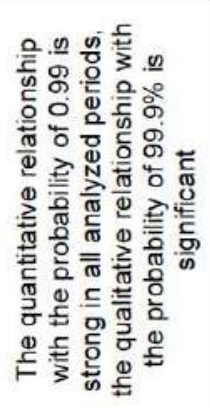 & 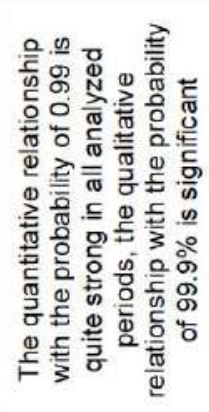 & 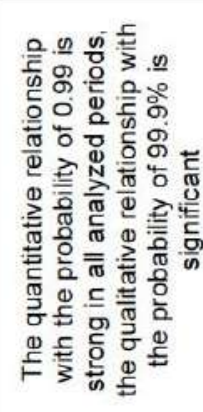 \\
\hline \multirow{6}{*}{ 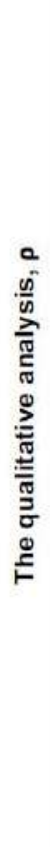 } & 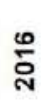 & $\begin{array}{ll}0 & \text { के } \\
0 & 0 \\
0 & \text { II }\end{array}$ & 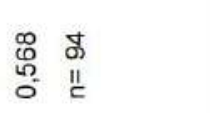 & 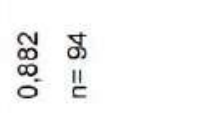 & 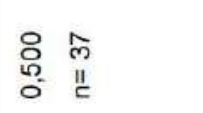 \\
\hline & ลั & 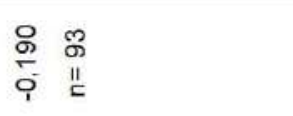 & $\begin{array}{ll}\text { 尺ू } & \text { న } \\
0 \\
0\end{array}$ & 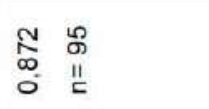 & 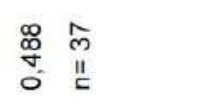 \\
\hline & $\frac{\pi}{\sigma}$ & $\begin{array}{ll}\frac{\infty}{c} & \& \\
& 11\end{array}$ & $\begin{array}{ll}\circ & \mathscr{0} \\
0 & 0 \\
0 & 11\end{array}$ & 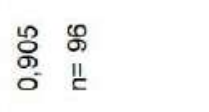 & 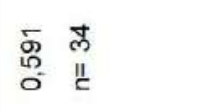 \\
\hline & $\stackrel{\infty}{\sigma}^{m}$ & 융 힝 & $\begin{array}{ll}\overline{0} & \overline{0} \\
0 & \\
0 & \end{array}$ & 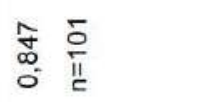 & 量 $\hat{~}$ \\
\hline & $\frac{\text { กั }}{2}$ & 志 & 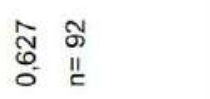 & $\begin{array}{ll}\stackrel{0}{0} & \bar{\sigma} \\
0 & 11\end{array}$ & 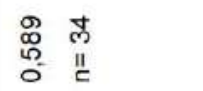 \\
\hline & $\bar{a}^{-}$ & $\begin{array}{ll}0 & 0 \\
0 & 0 \\
0 & 0\end{array}$ & 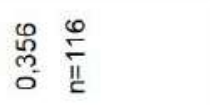 & $\underset{\substack{\hat{\infty} \\
0 \\
0 \\
0}}{\stackrel{\bar{N}}{I I}}$ & 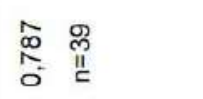 \\
\hline \multirow{6}{*}{ 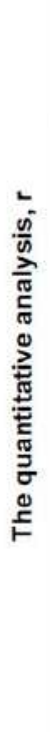 } & 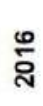 & 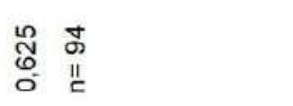 & 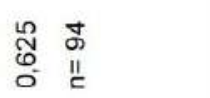 & $\begin{array}{ll}\overline{0} & \text { J } \\
0 \\
0 & 11\end{array}$ & 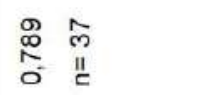 \\
\hline & ำ & స & 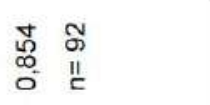 & 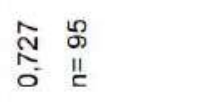 & \begin{tabular}{ll}
9 & \multicolumn{1}{c}{} \\
0 & 0 \\
0 & 11
\end{tabular} \\
\hline & $\frac{\text { ก }}{2}$ & $\begin{array}{ll}\text { 을 } & 8 \\
\text { in } & 11 \\
0 & \end{array}$ & 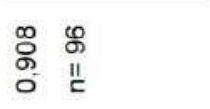 & 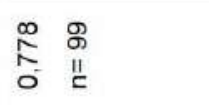 & 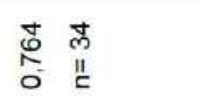 \\
\hline & $\stackrel{m}{N}^{m}$ & 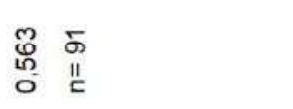 & $\begin{array}{ll}\bar{g} & 5 \\
0 \\
0 & 11\end{array}$ & 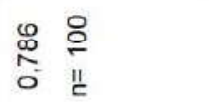 & 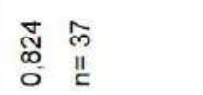 \\
\hline & กั & 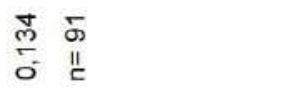 & 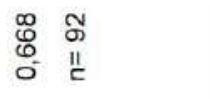 & 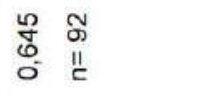 & $\begin{array}{ll}\text { 员 } & \text { m } \\
0 & \text { II }\end{array}$ \\
\hline & $\bar{N}_{\bar{N}}$ & $\begin{array}{ll}0 & \mathscr{O} \\
\stackrel{0}{0} & 0 \\
0 & \stackrel{1}{L}\end{array}$ & 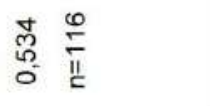 & 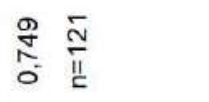 & 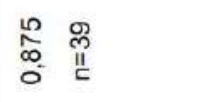 \\
\hline \multicolumn{2}{|c|}{ 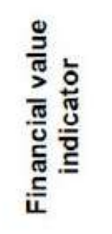 } & 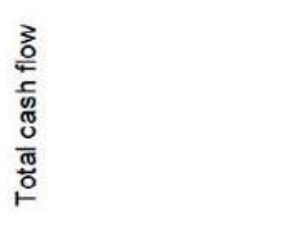 & 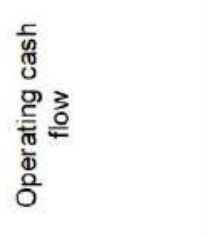 & 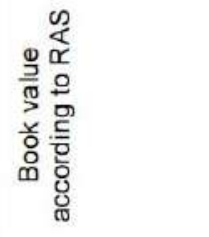 & 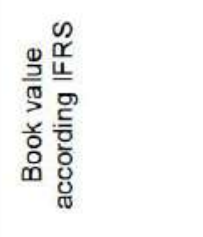 \\
\hline
\end{tabular}


Table 2: The Equations of Linear Regress for Size of Capitalization of the Organizations (y) in 2011-2016

\begin{tabular}{|c|c|c|}
\hline Variable (x) & Kind of the equation $^{\dagger}$ & $r^{2}$ \\
\hline \multicolumn{3}{|c|}{2011} \\
\hline Value on the total cash flow & $7381801252,8+0,3 x$ & 0,57 \\
\hline Value on an operating cash flow & $19463371198,5+0,49 x$ & 0,29 \\
\hline Book value according RAS & $1743994286,3+1,22 x$ & 0,56 \\
\hline Value on the total cash flow & $235730908922,7+0,56 x$ & 0,02 \\
\hline Value on an operating I cash flow & $129462555158,1+0,51 x$ & 0,45 \\
\hline Book value according RAS & $150915249082,91+0,51 x$ & 0,42 \\
\hline Book value according IFRS & $390680429966,2+0,39 x$ & 0,35 \\
\hline Value on an operating cash flow & $53714551247,2+0,4 x$ & 0,87 \\
\hline Book value according RAS & $82344385073,7+0,45 x$ & 0,62 \\
\hline Book value according IFRS & $179347195713,8+0,36 x$ & 0,68 \\
\hline \multicolumn{3}{|c|}{2014} \\
\hline Value on the total cash flow & $51101586291,3+0,36 x$ & 0,36 \\
\hline Value on an operating cash flow & $51101586291,3+0,36 x$ & 0,82 \\
\hline Book value according RAS & $81446252688,09+0,38 x$ & 0,61 \\
\hline Book value according IFRS & $218507696700,89+0,31 x$ & 0,58 \\
\hline Value on the total cash flow & $-33394000801,45+0,25 x$ & 0,36 \\
\hline Value on an operational cash flow & $139912015291,28+0,4 x$ & 0,39 \\
\hline Book value according RAS & $139271760726,04+0,42 x$ & 0,46 \\
\hline Book value according IFRS & $254911549837,77+0,4 x$ & 0,62 \\
\hline
\end{tabular}

${ }^{\dagger}$ All calculations were made in Russian rubbles.

The results show that $r^{2}$ of capitalization is higher to book value, than $r^{2}$ of value determined by cash flows in 2011 and 2016. This circumstance confirms typical difference of results of income capitalization and comparative approaches in an estimation of business ' value.

However, level of capitalization and business value calculated by operational and equity cash flows in researched periods relates as $40 \%-50 \%$, that shows underestimation of Russian companies from 2011 to 2016.
After carrying out of the analysis of interrelation of the price and value the authors lead the analysis of influence of some financial parameters on value and the price of business (see the results presented in Tables 3-6). The number of such financial parameters includes: Current liquidity ratio working capital in current liabilities, Equity in total assets ratio, D/E, Assets turnover, Equity turnover, Return of Assets, Return of equity, Return of sales. These coefficients are included in the vast majority of financial analysis methods. 
Ref. RTSI index 2011-2016.

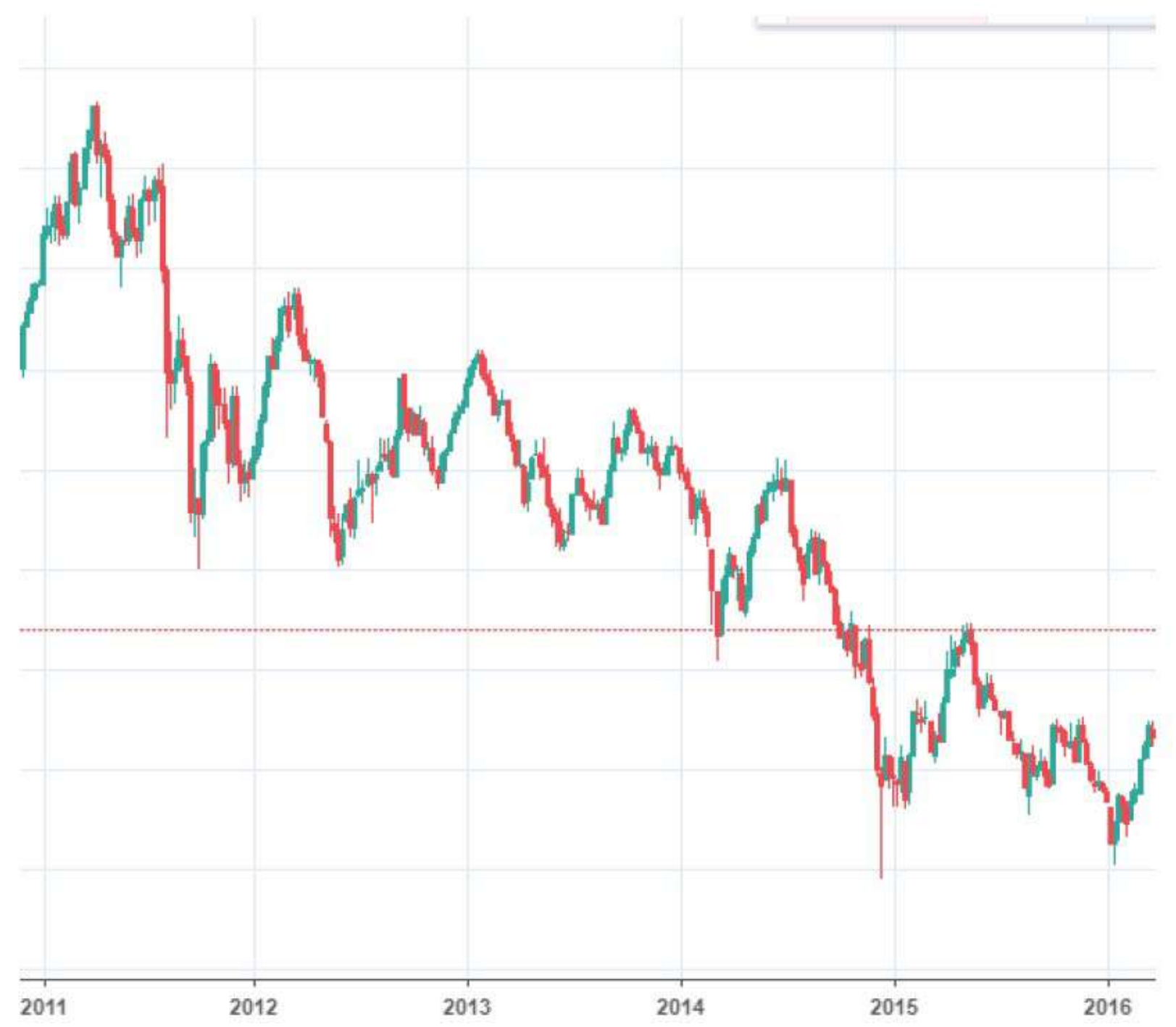

\section{CONCLUSION}

As a result of the analysis of the effect of financial ratios on the value obtained by different methods and companies capitalization, we indicate the lack of quantitative dependence. Rare ratios and of separate indicators have quality relation to business value and capitalization.

Among such relationships can be attributed for most of the periods analyzed:

- $\quad$ connection between value of business, received on the total cash flow and the quick ratio, the return on sales in certain periods (Table 3 );

- connection between value of business, received on the operational actual cash flow and the factor of autonomy, return of assets, the profitability of sales in certain periods (Table 4);

- the obvious relation which has found acknowledgement between book value of own capital according to RAS and factor of autonomy (in numerator of autonomy coefficient we use equity book value, according to RAS, that is the second analyzed parameter), the profitability of actives, the profitability of sales in certain periods (Table 5);

- connection between level of capitalization and the profitability of sales, factor of autonomy (Table 6).

Influences of parameters on book value of equity according to IFRS has not been revealed. 


\begin{tabular}{|c|c|c|c|c|c|c|}
\hline 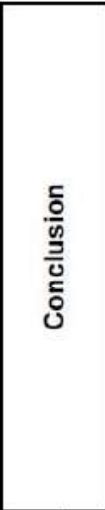 & 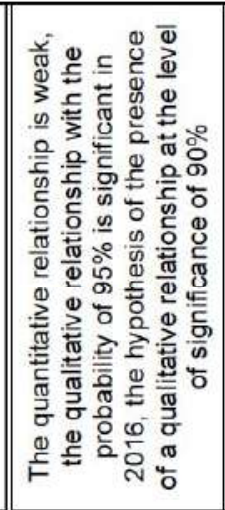 & 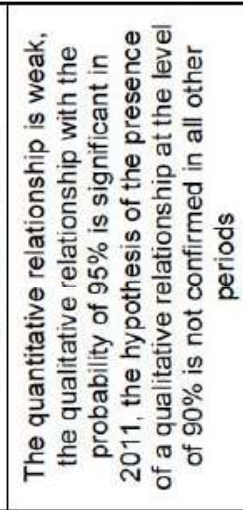 & 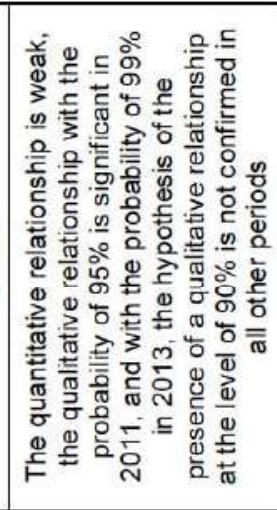 & 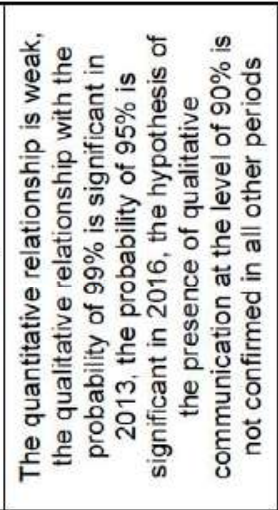 & 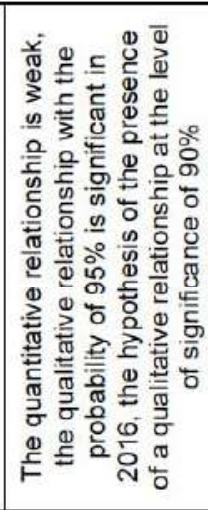 & 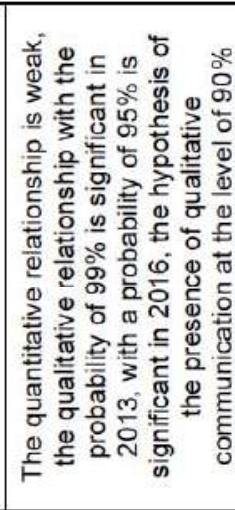 \\
\hline$\stackrel{\circ}{\stackrel{2}{*}}$ & $\stackrel{F}{\risingdotseq}$ & 홍 & 总 & 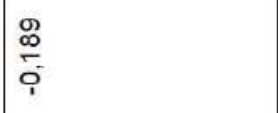 & $\begin{array}{l}\text { : } \\
\text { : } \\
i\end{array}$ & 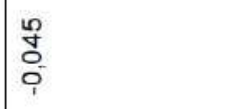 \\
\hline | & $\mid$\begin{tabular}{|l|l}
$\mid \infty$ \\
0 \\
0
\end{tabular} & $\stackrel{0}{\frac{0}{0}}$ & $\frac{\bar{\tau}}{\bar{i}}$ & $\frac{0}{0}$ & $\begin{array}{l}0 \\
\vdots \\
0\end{array}$ & 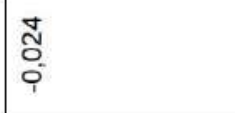 \\
\hline 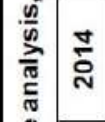 & 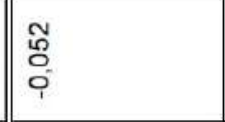 & 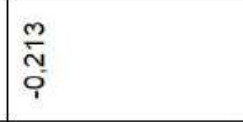 & 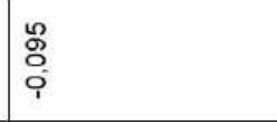 & $\frac{8}{0}$ & 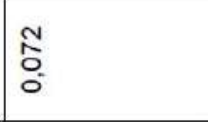 & $\frac{\text { vo }}{0}$ \\
\hline 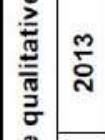 & $\mid \begin{array}{l}\mid \frac{\pi}{0} \\
0\end{array}$ & 尊 & 总 & 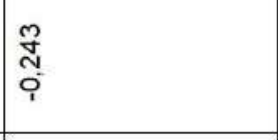 & 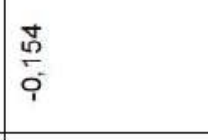 & 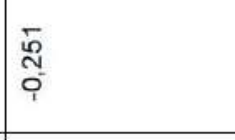 \\
\hline مَّ & $\mid$\begin{tabular}{||c|c}
$\infty$ \\
0 \\
0 \\
0
\end{tabular} & $\begin{array}{l}0 \\
0 \\
0 \\
0 \\
0 \\
1\end{array}$ & 各 & 总 & $\begin{array}{l}\frac{1}{2} \\
\frac{1}{0} \\
0\end{array}$ & \begin{tabular}{|l}
$\bar{q}$ \\
0 \\
0 \\
0
\end{tabular} \\
\hline స్̀ & 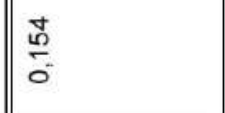 & 总 & $\begin{array}{l}\mathcal{N} \\
\text { ปै } \\
0\end{array}$ & $\frac{\pi}{0}$ & 怘 & 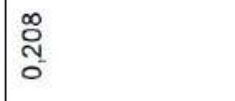 \\
\hline ํㅜㄹ & $\mid$\begin{tabular}{|l}
$\mid \hat{\theta}$ \\
$\stackrel{0}{0}$
\end{tabular} & $\begin{array}{l}\text { ô } \\
\text { o. } \\
\text { o. }\end{array}$ & $\frac{7}{\mathcal{7}}$ & $\begin{array}{l}\text { के } \\
\text { o. }\end{array}$ & 足 & $\begin{array}{l}\hat{\omega} \\
0 \\
0 \\
0\end{array}$ \\
\hline$=\sum_{i}^{\infty}$ & $\mid \begin{array}{l}\text { | } \\
0 \\
0\end{array}$ & $\begin{array}{l}\text { జू } \\
\text { o. }\end{array}$ & 商 & $\begin{array}{l}\hat{o} \\
\stackrel{0}{0}\end{array}$ & $\begin{array}{l}\text { on } \\
\text { ờ }\end{array}$ & 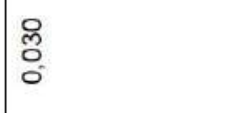 \\
\hline 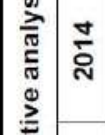 & $\mid \begin{array}{l}n \\
\vdots \\
0 \\
0\end{array}$ & 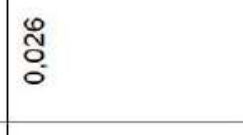 & \%̊ & $\begin{array}{l}\text { Dू } \\
\text { ơ }\end{array}$ & 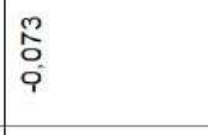 & $\begin{array}{l}\hat{\hat{D}} \\
0 \\
0 \\
0\end{array}$ \\
\hline 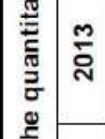 & 送 & $\begin{array}{l}0 \\
\stackrel{2}{0} \\
0 \\
0\end{array}$ & $\frac{\bar{m}}{0}$ & 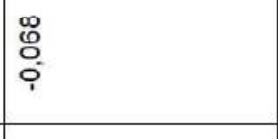 & 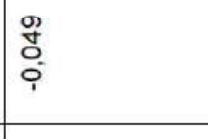 & $\begin{array}{l}\text { yo } \\
0 \\
0 \\
0\end{array}$ \\
\hline స̃ & $\mid \frac{5}{0}$ & $\begin{array}{l}\text { : } \\
:\end{array}$ & $\frac{0}{\stackrel{0}{0}}$ & $\begin{array}{l}0 \\
\vdots \\
0 \\
i\end{array}$ & 总 & $\begin{array}{l}\bar{\alpha} \\
\overline{0} \\
\bar{i}\end{array}$ \\
\hline స్̀ & \begin{tabular}{|l|l}
0 \\
0 \\
0 \\
0 \\
0
\end{tabular} & $\begin{array}{l}\frac{1}{0} \\
\bar{c} \\
\bar{c}\end{array}$ & 峁 & \begin{tabular}{|l}
$\tilde{n}$ \\
0 \\
0 \\
$i$
\end{tabular} & 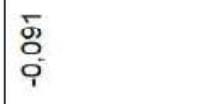 & $\begin{array}{l}\hat{o} \\
\text { o. } \\
\text { o. }\end{array}$ \\
\hline 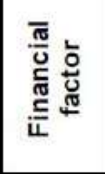 & 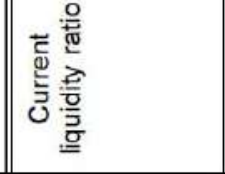 & 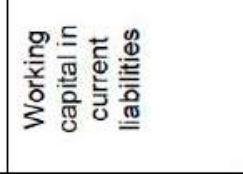 & 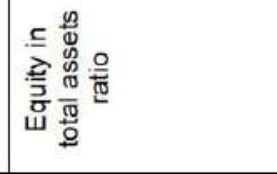 & Шّ & 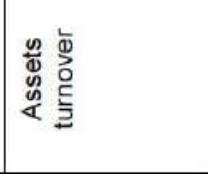 & 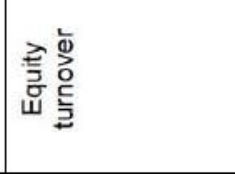 \\
\hline
\end{tabular}




\begin{tabular}{|c|c|c|}
\hline 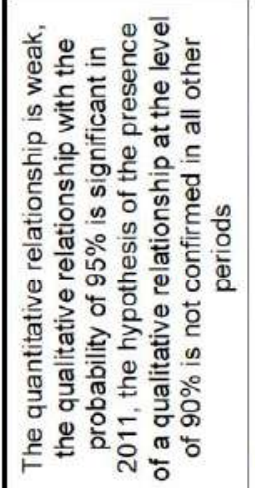 & 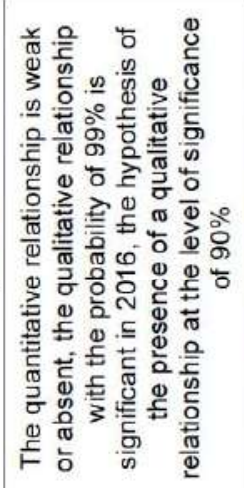 & 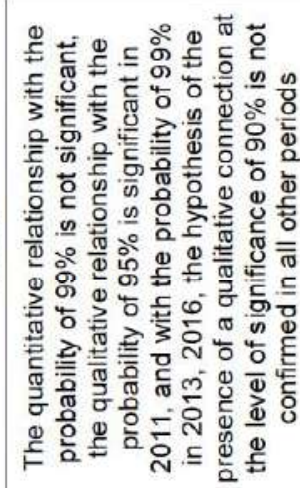 \\
\hline $\begin{array}{l}\hat{0} \\
\text { o }\end{array}$ & $\begin{array}{l}0 \\
\vdots \\
\vdots \\
0\end{array}$ & $\stackrel{\mathscr{m}}{0}$ \\
\hline $\begin{array}{l}\text { पे } \\
\text { O. } \\
\text { i }\end{array}$ & $\begin{array}{l}\text { Õ } \\
\text { Oे } \\
\text { i }\end{array}$ & $\begin{array}{l}\text { O̊ } \\
\text { : } \\
\text { i }\end{array}$ \\
\hline $\begin{array}{l}\text { ?̊ } \\
\text { Oे } \\
0\end{array}$ & $\begin{array}{l}\infty \\
\stackrel{\infty}{0} \\
0 . \\
0\end{array}$ & $\frac{\mathscr{q}}{\stackrel{+}{L}}$ \\
\hline$\frac{\widetilde{m}}{\circ}$ & $\begin{array}{l}\text { مू } \\
\text { :- }\end{array}$ & 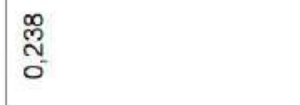 \\
\hline $\begin{array}{l}\circ \\
: \\
0 \\
\\
\end{array}$ & $\frac{0}{i}$ & $\begin{array}{l}\text { षे } \\
\text { O }\end{array}$ \\
\hline 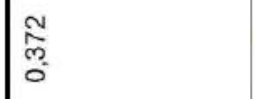 & 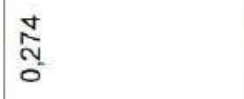 & 号 \\
\hline $\begin{array}{l}\text { đू } \\
\text { O- }\end{array}$ & $\begin{array}{l}\bar{\delta} \\
0\end{array}$ & $\begin{array}{c}\underset{N}{N} \\
\text { O }\end{array}$ \\
\hline$\frac{\pi}{0}$ & $\begin{array}{l}\text { J } \\
0 \\
0\end{array}$ & $\begin{array}{l}\text { चี } \\
0\end{array}$ \\
\hline $\begin{array}{l}\text { స్ } \\
\text { ర్ }\end{array}$ & $\begin{array}{l}\text { む } \\
\text { ○ }\end{array}$ & $\begin{array}{l}0 \\
\text { İ } \\
0\end{array}$ \\
\hline $\begin{array}{l}\stackrel{0}{0} \\
0 \\
0\end{array}$ & $\begin{array}{l}\tilde{m} \\
\tilde{o} \\
0 \\
i\end{array}$ & $\begin{array}{l}\stackrel{\infty}{0} \\
\vdots \\
0\end{array}$ \\
\hline$\stackrel{\infty}{\vdots}$ & $\begin{array}{l}8 \\
0 \\
0\end{array}$ & Iี \\
\hline $\begin{array}{l}\text { 음 } \\
0\end{array}$ & $\begin{array}{l}\text { L̊ } \\
0 \\
\end{array}$ & $\begin{array}{l}\text { 尺े } \\
\text { : }\end{array}$ \\
\hline 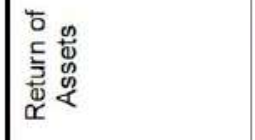 & 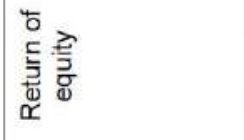 & 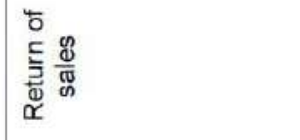 \\
\hline
\end{tabular}

\begin{tabular}{|c|c|c|c|}
\hline $\begin{array}{l}0 \\
\frac{0}{y} \\
0 \\
0 \\
0 \\
0\end{array}$ & & 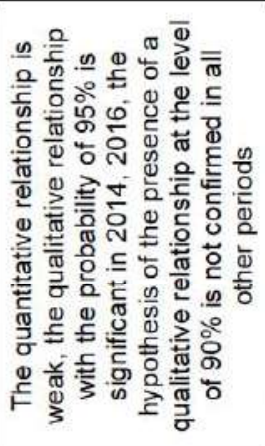 & 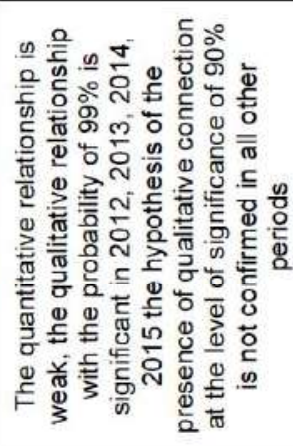 \\
\hline & $\stackrel{\sim}{\stackrel{N}{*}}$ & ষ্ণ & $\begin{array}{l}0 \\
\stackrel{0}{0} \\
-\end{array}$ \\
\hline a & ஸొ & 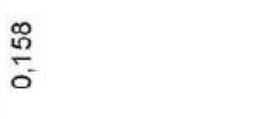 & $\begin{array}{l}\bar{c} \\
\text { i }\end{array}$ \\
\hline 然 & ষ্ণ & 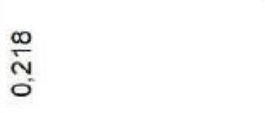 & $\begin{array}{l}\text { J } \\
\text { ల్ } \\
\text { i }\end{array}$ \\
\hline 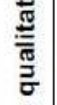 & $\sum_{\text {Dे }}^{m}$ & $\frac{\stackrel{m}{\frac{m}{0}}}{0}$ & 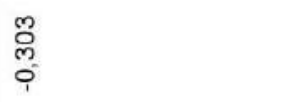 \\
\hline & $\stackrel{\sim}{\grave{N}}$ & $\stackrel{\widehat{o}}{0}$ & $\begin{array}{l}\text { Na } \\
\text { N̦ } \\
i\end{array}$ \\
\hline & $\stackrel{\bar{c}}{\bar{c}}$ & 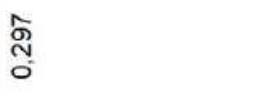 & $\begin{array}{l}\overline{0} \\
0 \\
0\end{array}$ \\
\hline & $\stackrel{\circ}{\stackrel{\alpha}{\alpha}}$ & $\begin{array}{l}\hat{\circ} \\
0\end{array}$ & $\begin{array}{l}\text { గ్ర } \\
0 \\
0\end{array}$ \\
\hline 2 & $\stackrel{\infty}{\tilde{N}}$ & $\begin{array}{l}\hat{o} \\
\text { o. }\end{array}$ & $\begin{array}{l}\infty \\
0 \\
0 \\
0 \\
i\end{array}$ \\
\hline 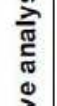 & ¿্র & 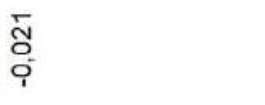 & $\begin{array}{l}\text { \& } \\
\text { \& } \\
\end{array}$ \\
\hline 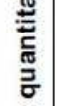 & సं & $\begin{array}{l}\text { षे } \\
\text { : }\end{array}$ & 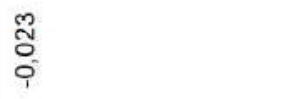 \\
\hline$F$ & సั. & $\frac{N}{\frac{1}{0}}$ & $\begin{array}{l}\text { ¿n } \\
0 \\
0\end{array}$ \\
\hline & స్ন & $\begin{array}{l}00 \\
0 \\
\\
\end{array}$ & $\stackrel{0}{0}_{0}^{\infty}$ \\
\hline \multicolumn{2}{|c|}{ 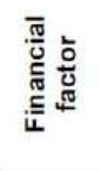 } & 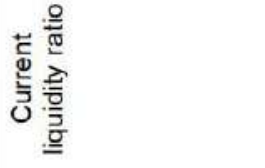 & 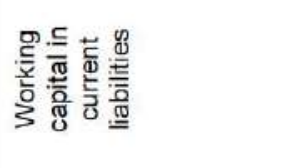 \\
\hline
\end{tabular}




\begin{tabular}{|c|c|c|c|c|c|c|}
\hline 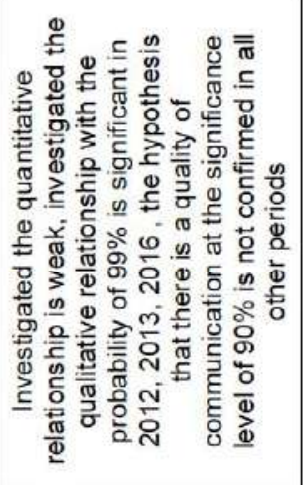 & 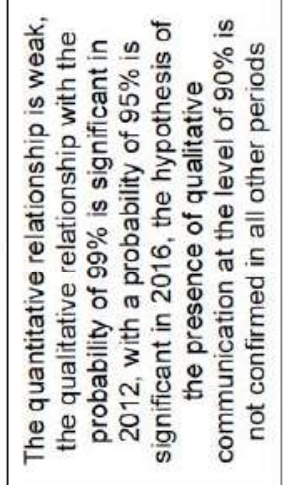 & 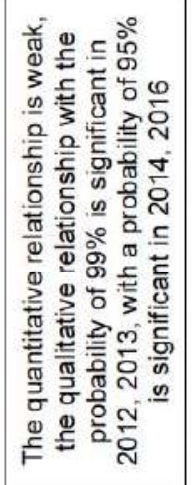 & 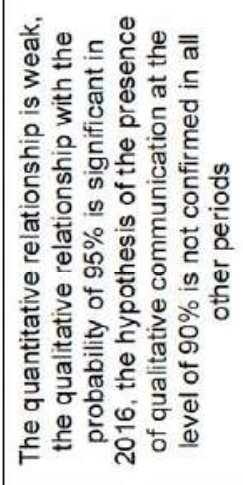 & 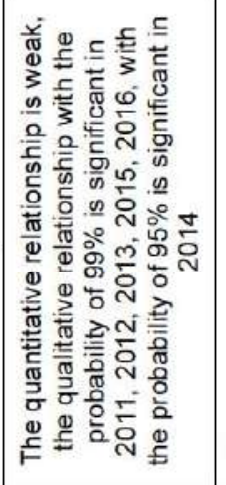 & 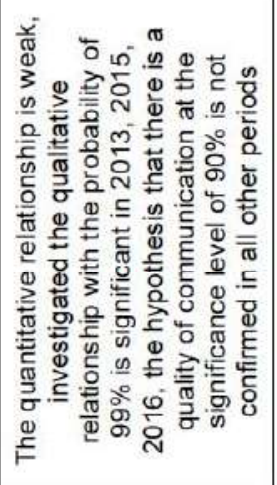 & 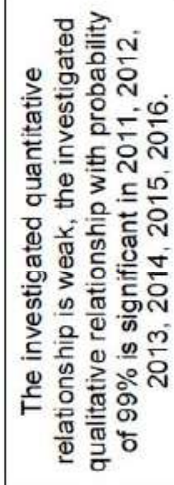 \\
\hline 怘 & $\frac{\mathbb{D}}{\frac{\mathbf{\sigma}}{i}}$ & $\begin{array}{l}\text { ò } \\
\text { त̄ } \\
\text { ì }\end{array}$ & ્్ָָ & 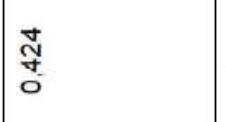 & 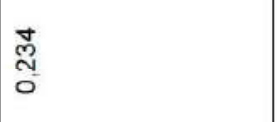 & $\begin{array}{l}0 \\
0 \\
0 \\
0 \\
0\end{array}$ \\
\hline ָָ & 음 & 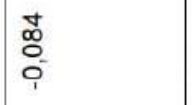 & $\frac{\widetilde{\sigma}}{0}$ & స్ల్ & 㐫 & 导 \\
\hline$\frac{\Phi}{0}$ & 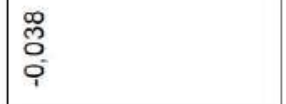 & $\frac{\infty}{\circ}$ & : & 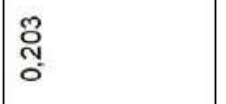 & $\frac{8}{0}$ & 売 \\
\hline 总 & $\frac{\stackrel{\circ}{\circ}}{9}$ & 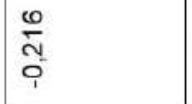 & $\frac{\bar{\sigma}}{\bar{\varphi}}$ & 章 & 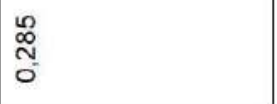 & 岕 \\
\hline 吕 & $\begin{array}{c}\text { : } \\
\text { o. } \\
\text { Q }\end{array}$ & $\underset{\substack{\text { N్ } \\
\text { ị }}}{ }$ & 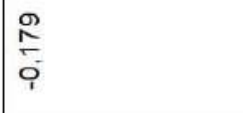 & $\begin{array}{l}\mathscr{O} \\
\stackrel{\tilde{c}}{0}\end{array}$ & $\stackrel{\infty}{\frac{\infty}{0}}$ & 点 \\
\hline 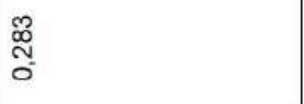 & $\frac{\Phi}{\bar{\phi}}$ & $\begin{array}{l}0 \\
: \\
0 \\
0\end{array}$ & 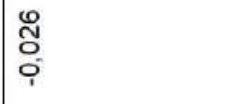 & 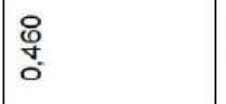 & 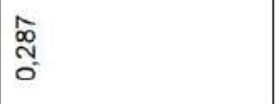 & 発 \\
\hline$\frac{\mathfrak{Z}}{0}$ & $\begin{array}{l}\overline{\text { ğ }} \\
\text { ó }\end{array}$ & $\frac{n}{\frac{n}{i}}$ & $\begin{array}{l}\text { ò } \\
\text { ơ } \\
\text { ì }\end{array}$ & 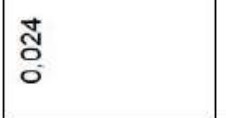 & $\begin{array}{l}\bar{\alpha} \\
\text { ò }\end{array}$ & 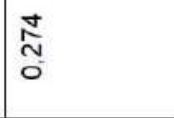 \\
\hline ֶָّ & 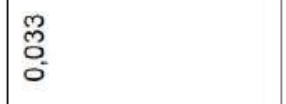 & $\overbrace{i}^{n}$ & $\begin{array}{l}\overline{\widehat{o}} \\
\bar{c}\end{array}$ & 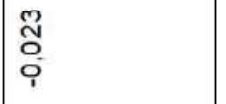 & $\begin{array}{l}\text { 苑 } \\
\text { O. }\end{array}$ & $\frac{0}{0}$ \\
\hline ڤัٌ & : & $\frac{\pi}{i}$ & $\begin{array}{l}\text { ỹ } \\
\text { ơ } \\
\text { in }\end{array}$ & $\begin{array}{l}\hat{o} \\
0 \\
o\end{array}$ & 商 & $\stackrel{\leftrightarrow}{\circ}$ \\
\hline 兽 & $\begin{array}{l}\text { o } \\
\text { ò } \\
\end{array}$ & $\frac{\bar{o}}{\bar{c}}$ & 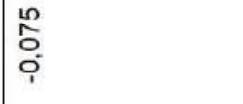 & $\begin{array}{l}\text { J } \\
\text { Oे }\end{array}$ & $\begin{array}{l}\text { Oू } \\
\text { o. }\end{array}$ & $\stackrel{0}{0}$ \\
\hline$\frac{\text { 㝵 }}{0}$ & $\underset{c}{\tilde{G}}$ & $\frac{50}{6}$ & $\begin{array}{l}\text { 品 } \\
\text { o. }\end{array}$ & $\begin{array}{l}\text { 吕 } \\
\text { O. }\end{array}$ & $\begin{array}{l}\text { 总 } \\
\text { o. }\end{array}$ & $\frac{\mathscr{2}}{\stackrel{\circ}{0}}$ \\
\hline 莡 & 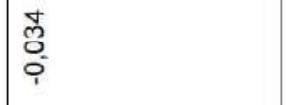 & 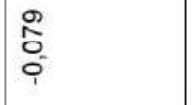 & 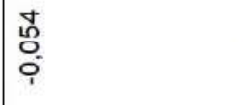 & $\stackrel{\stackrel{\leftrightarrow}{\circ}}{\circ}$ & 总 & $\stackrel{\infty}{0}$ \\
\hline 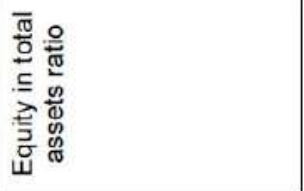 & Щ্ّ & 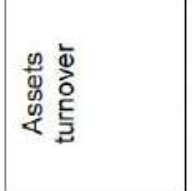 & 或高 & 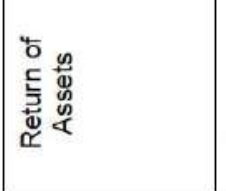 & 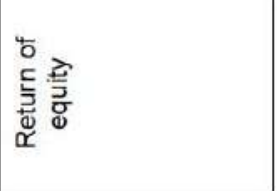 & 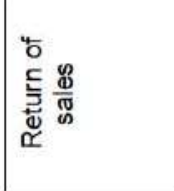 \\
\hline
\end{tabular}




\begin{tabular}{|c|c|c|c|c|c|c|}
\hline 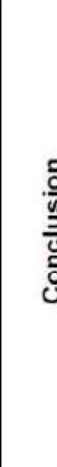 & & 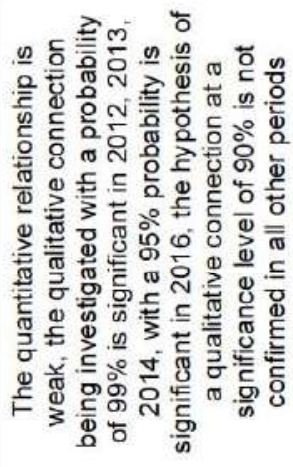 & 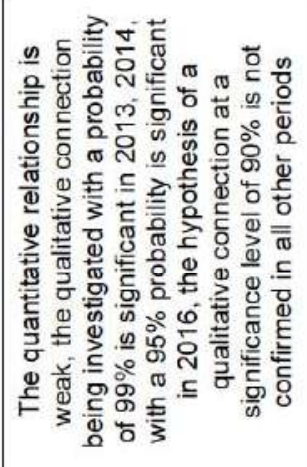 & 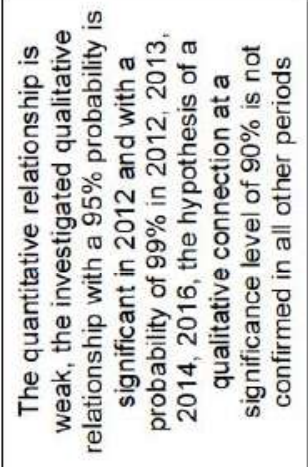 & 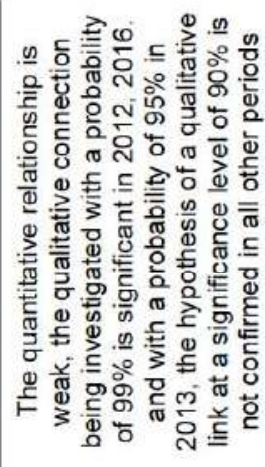 & 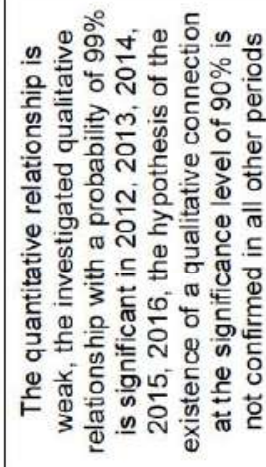 \\
\hline \multirow{6}{*}{ 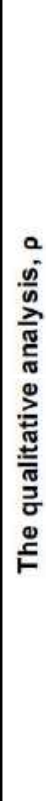 } & $\stackrel{\sim}{\check{N}}$ & 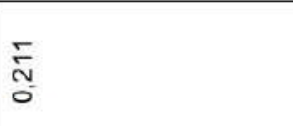 & 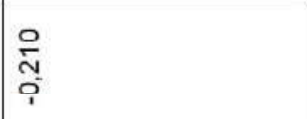 & $\begin{array}{l}\text { \&్ల } \\
\text { O } \\
0\end{array}$ & 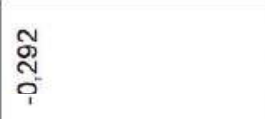 & $\begin{array}{c}\text { \%్ల } \\
\text { ị }\end{array}$ \\
\hline & సั. & $\begin{array}{l}\text { ஜू } \\
0 \\
0\end{array}$ & $\frac{\alpha}{\sigma}$ & $\begin{array}{l}\hat{\omega} \\
\text { c. } \\
0\end{array}$ & 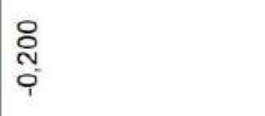 & 胥 \\
\hline & गे & ्ָञ & \begin{tabular}{l} 
ㅇ \\
\multirow{2}{*}{} \\
o
\end{tabular} & 足 & $\frac{9}{0}$ & 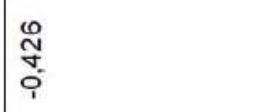 \\
\hline & $\stackrel{m}{\frac{m}{2}}$ & 总 & 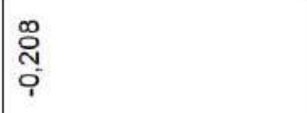 & $\begin{array}{l}0 \\
0 \\
0 \\
0 \\
0\end{array}$ & $\begin{array}{l}\bar{w} \\
\stackrel{n}{0} \\
i\end{array}$ & 움 \\
\hline & $\stackrel{\sim}{\tilde{N}}$ & స్న & $\frac{\mathscr{0}}{\frac{0}{0}}$ & $\begin{array}{l}\bar{\sigma} \\
0 \\
0\end{array}$ & 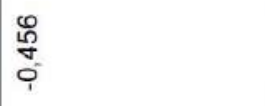 & $\begin{array}{l}n \\
\tilde{n} \\
0 \\
i\end{array}$ \\
\hline & $\overline{\check{n}}$ & $\frac{N}{\frac{N}{0}}$ & đ̃ & $\begin{array}{l}\text { م⿱ 口م } \\
0 \\
0\end{array}$ & 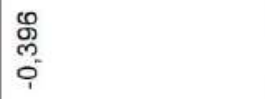 & $\frac{\hat{o}}{0 .}$ \\
\hline \multirow{6}{*}{ 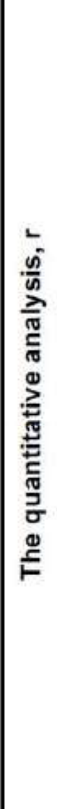 } & $\stackrel{\circ}{\grave{n}}$ & $\begin{array}{l}\text { ్ㅣㅇ } \\
\text { O. }\end{array}$ & $\stackrel{\infty}{\vdots}$ & $\stackrel{F}{E}$ & $\begin{array}{l}\text { id } \\
\text { ô. }\end{array}$ & $\begin{array}{l}\infty \\
\text { o } \\
0 \\
\\
\end{array}$ \\
\hline & ถึ & 음 & $\begin{array}{l}\mathscr{O} \\
\text { O } \\
0\end{array}$ & $\frac{ㅇ}{0}$ & $\begin{array}{l}\text { og } \\
\text { o } \\
0 \\
\end{array}$ & $\begin{array}{l}\infty \\
0 \\
0 \\
0 \\
0\end{array}$ \\
\hline & $\frac{\text { ก }}{4}$ & $\begin{array}{l}\text { dे } \\
0 \\
0\end{array}$ & 옹 & $\frac{\text { o }}{\frac{0}{0}}$ & $\begin{array}{l}\text { } \\
\text { o } \\
0 \\
0\end{array}$ & $\begin{array}{l}\text { ò } \\
\text { o. } \\
\text { in }\end{array}$ \\
\hline & ก & $\begin{array}{l}\text { o } \\
\text { O }\end{array}$ & 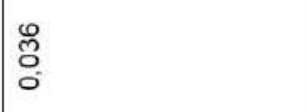 & $\frac{\text { Iิ }}{0}$ & $\begin{array}{l}\infty \\
0 \\
0 \\
0 \\
0\end{array}$ & 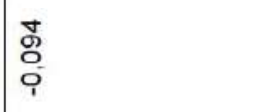 \\
\hline & $\stackrel{\sim}{\tilde{N}}$ & $\begin{array}{l}\text { ㅇ. } \\
\text { o. } \\
\text { - }\end{array}$ & $\begin{array}{l}\hat{0} \\
\text { O }\end{array}$ & $\frac{n}{0}$ & $\frac{n}{0}$ & $\frac{n}{0}$ \\
\hline & $\overline{\grave{n}}$ & $\begin{array}{l}\hat{o} \\
\bar{i}\end{array}$ & o & $\underset{\text { N }}{\text { N }}$ & ֶ̃ & $\frac{\widetilde{N}}{i}$ \\
\hline 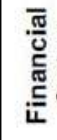 & 总 & 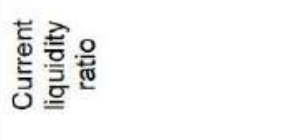 & 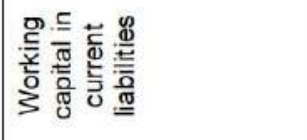 & 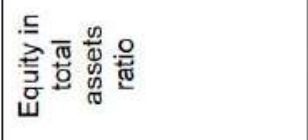 & 山্ & 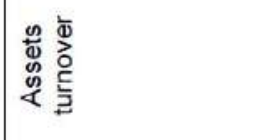 \\
\hline
\end{tabular}




\begin{tabular}{|c|c|c|c|}
\hline 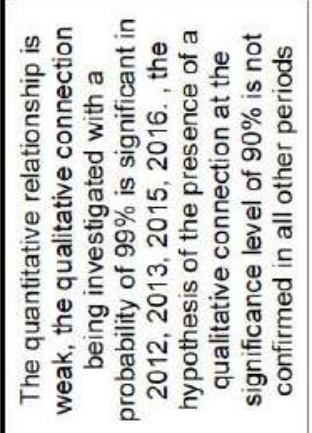 & 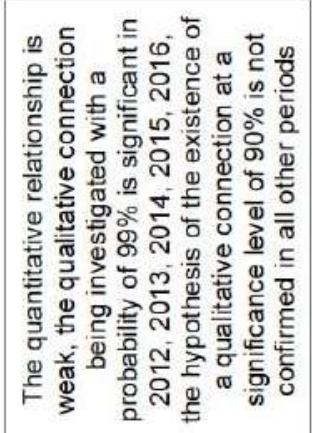 & 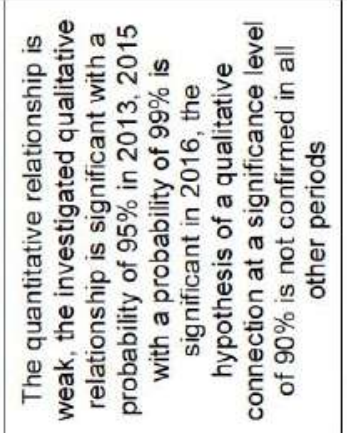 & 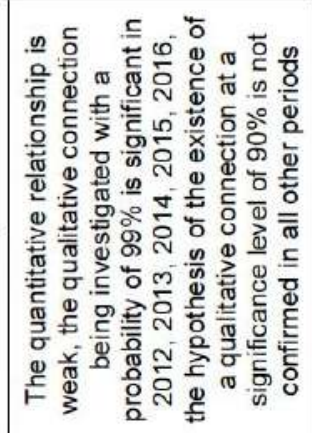 \\
\hline 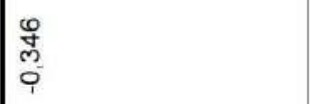 & 䊬 & 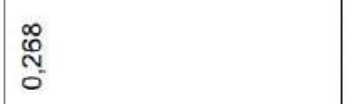 & 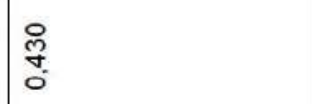 \\
\hline 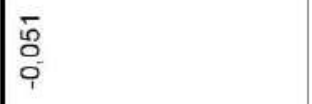 & $\frac{\mathscr{\infty}}{0}$ & $\frac{\stackrel{p}{0}}{0}$ & 黑 \\
\hline 芯 & $\frac{m}{m}$ & $\begin{array}{l}\infty \\
\stackrel{\infty}{0} \\
0\end{array}$ & \begin{tabular}{|l} 
㝵 \\
0 \\
0 \\
0
\end{tabular} \\
\hline 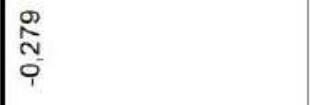 & $\begin{array}{l}\text { fo } \\
\text { m } \\
0\end{array}$ & $\begin{array}{l}\text { D̊ } \\
\text { O. }\end{array}$ & 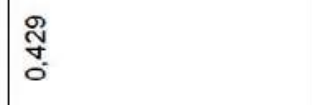 \\
\hline 京 & $\begin{array}{l}\overline{0} \\
\text { o. } \\
0\end{array}$ & $\frac{\mathbb{N}}{0}$ & 总 \\
\hline 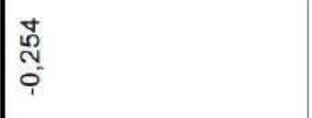 & $\frac{\mathscr{0}}{0}$ & $\stackrel{\varphi}{\frac{\varphi}{i}}$ & 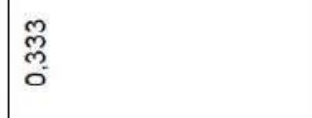 \\
\hline 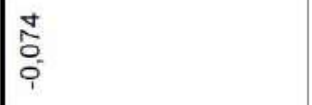 & $\begin{array}{l}n \\
0 \\
0 \\
0\end{array}$ & $\begin{array}{l}0 \\
\stackrel{8}{0} \\
\text { co }\end{array}$ & $\begin{array}{l}0 \\
0 \\
0 \\
0 \\
0\end{array}$ \\
\hline 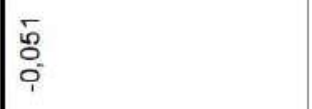 & $\begin{array}{l}\text { Ju } \\
\text { ô. }\end{array}$ & $\begin{array}{l}\text { : } \\
\text { : }\end{array}$ & $\begin{array}{l}8 \\
0 \\
0\end{array}$ \\
\hline 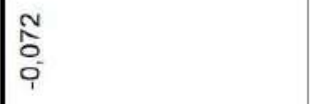 & $\begin{array}{l}\text { of } \\
0 \\
0\end{array}$ & $\begin{array}{l}\text { đo } \\
\text { o. } \\
\end{array}$ & 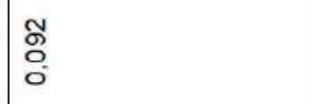 \\
\hline 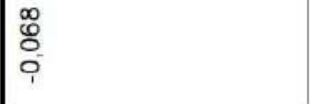 & $\begin{array}{l}0 \\
0 \\
0 \\
0\end{array}$ & $\begin{array}{l}\hat{\Delta} \\
\text { ò }\end{array}$ & $\frac{\pi}{0}$ \\
\hline $\begin{array}{c}\stackrel{8}{8} \\
\text { o. } \\
\\
\end{array}$ & $\begin{array}{l}\overline{0} \\
\text { o. }\end{array}$ & $\begin{array}{l}\infty \\
0 \\
0 \\
i\end{array}$ & $\underset{0}{\infty}$ \\
\hline 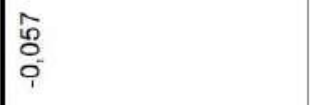 & 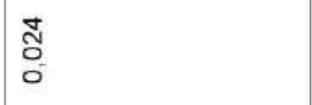 & $\begin{array}{l}\frac{m}{0} \\
c_{0}\end{array}$ & $\begin{array}{l}\tilde{\Xi} \\
0 \\
0\end{array}$ \\
\hline 忞衰 & 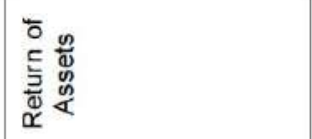 & 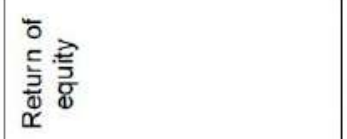 & 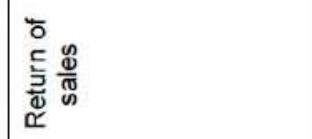 \\
\hline
\end{tabular}




\begin{tabular}{|c|c|c|c|c|c|}
\hline 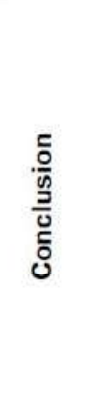 & 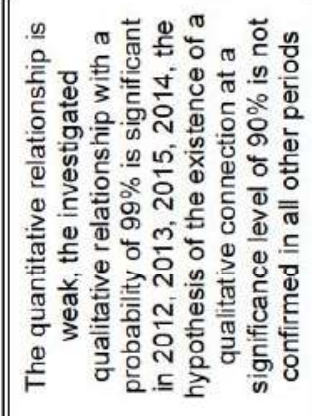 & 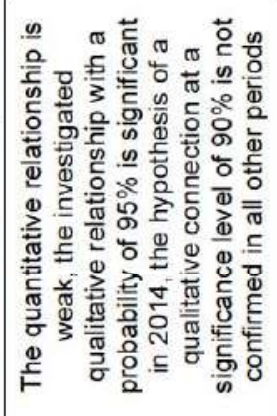 & 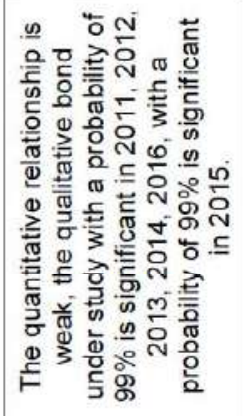 & 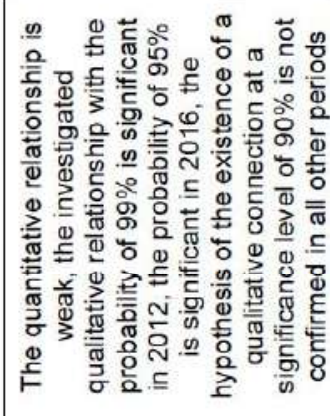 & 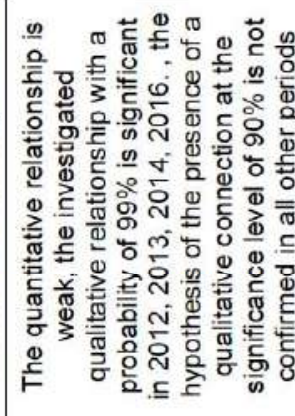 \\
\hline$\stackrel{0}{\grave{2}}$ & $\mid$\begin{tabular}{|l} 
总 \\
d
\end{tabular} & $\frac{5}{9}$ & 劲 & 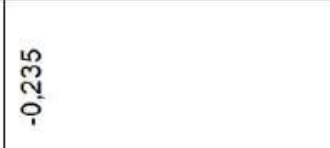 & 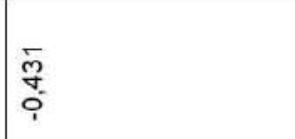 \\
\hline 望 & $\mid$\begin{tabular}{|l}
0 \\
0 \\
0 \\
0 \\
0
\end{tabular} & $\frac{n}{n}$ & ্ָָָ & 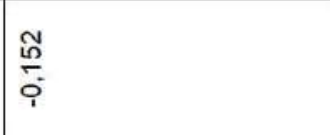 & 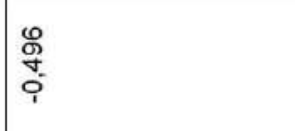 \\
\hline 竞 & 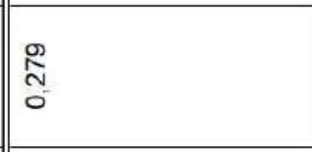 & 总 & 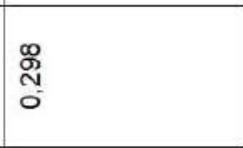 & $\begin{array}{l}\text { o } \\
\stackrel{0}{\circ} \\
\stackrel{0}{0}\end{array}$ & 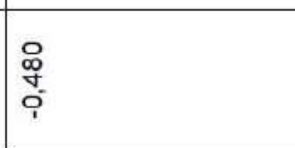 \\
\hline 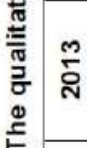 & 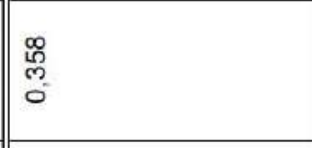 & $\frac{8}{\stackrel{8}{0}}$ & $\begin{array}{l}\frac{\omega}{0} \\
0 \\
0 \\
0\end{array}$ & $\begin{array}{l}0 \\
0 \\
0 \\
1\end{array}$ & $\begin{array}{l}\text { 年 } \\
\text { o }\end{array}$ \\
\hline$\stackrel{\sim}{\sim}$ & 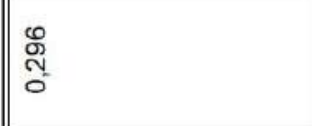 & إم & 是 & 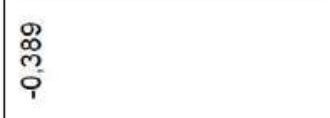 & 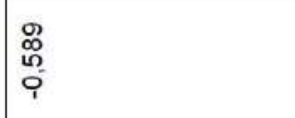 \\
\hline స̃ & 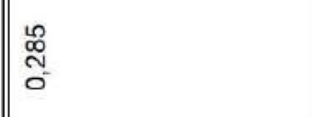 & 茴 & 旁 & $\frac{9}{0}$ & 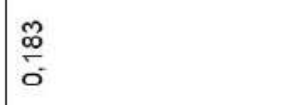 \\
\hline$\stackrel{\circ}{\stackrel{N}{N}}$ & $\mid \begin{array}{l}0 \\
\text { o. } \\
0\end{array}$ & 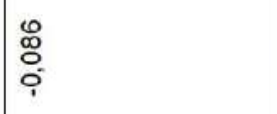 & 음 & 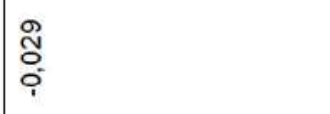 & 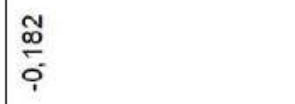 \\
\hline$=\stackrel{\infty}{\stackrel{n}{\Sigma}}$ & $\mid$\begin{tabular}{|l}
$\mid \frac{g}{0}$ \\
0
\end{tabular} & $\begin{array}{l}\text { 总 } \\
\text { ơ }\end{array}$ & : & $\begin{array}{l}\bar{c} \\
\bar{c} \\
\bar{i}\end{array}$ & 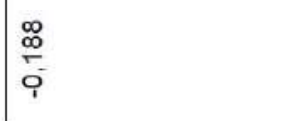 \\
\hline 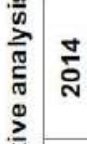 & $\begin{array}{l}\text { ò } \\
\text { o. }\end{array}$ & $\frac{\hat{N}}{\sigma_{0}^{\prime}}$ & 路 & 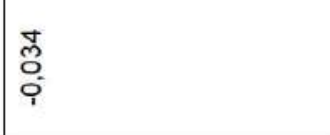 & $\frac{1}{\frac{\pi}{0}}$ \\
\hline 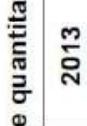 & $\mid \begin{array}{l}\infty \\
: \\
0\end{array}$ & 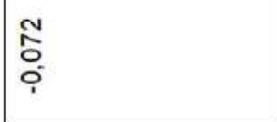 & go & $\begin{array}{l}\infty \\
0 \\
0 \\
0\end{array}$ & $\frac{d}{\frac{8}{9}}$ \\
\hline F & $\begin{array}{l}\text { \% } \\
\text { : } \\
\text { c. }\end{array}$ & | & 帝 & $\frac{\hat{f}}{i}$ & 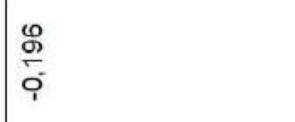 \\
\hline స्̀े & $\mid \begin{array}{ll}\pi \\
\vdots \\
0 \\
0 \\
\end{array}$ & 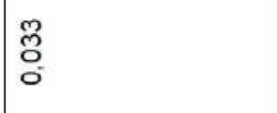 & Б) & $\begin{array}{l}0 \\
\text { ơ } \\
\text { ô }\end{array}$ & 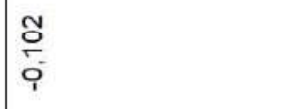 \\
\hline 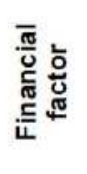 & 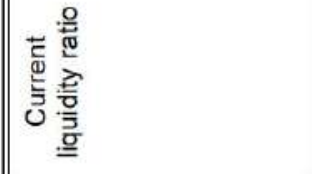 & 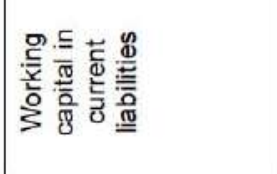 & 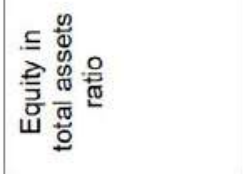 & 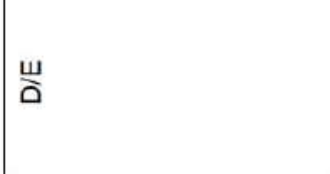 & 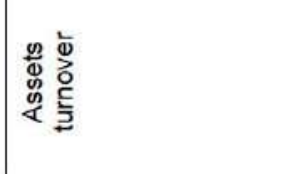 \\
\hline
\end{tabular}




\begin{tabular}{|c|c|c|c|}
\hline 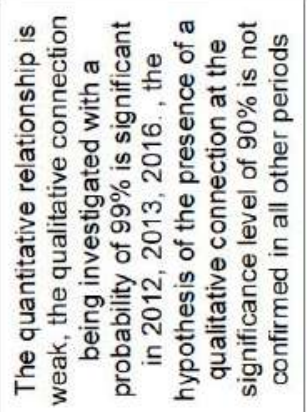 & 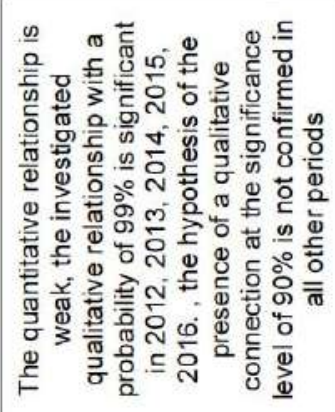 & 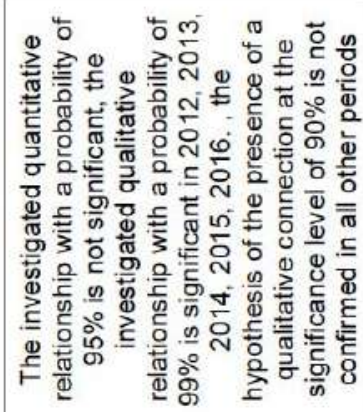 & 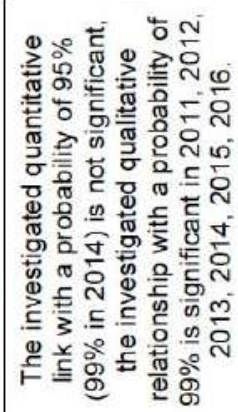 \\
\hline 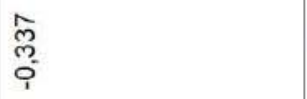 & $\begin{array}{l}\mathscr{0} \\
\tilde{\sigma} \\
0\end{array}$ & 울 & @o \\
\hline 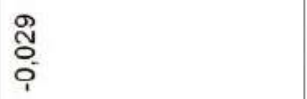 & 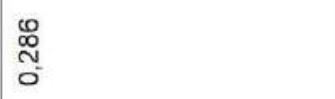 & $\begin{array}{l}\bar{\Sigma} \\
\text { Na } \\
0\end{array}$ & $\begin{array}{l}\overline{-} \\
\text { م⿱⺈ } \\
0\end{array}$ \\
\hline $\begin{array}{l}0 \\
0 \\
0 \\
0\end{array}$ & 용 & 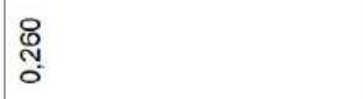 & $\begin{array}{l}\mathscr{2} \\
0 \\
0 \\
0\end{array}$ \\
\hline $\begin{array}{l}\bar{c} \\
\text { o. } \\
0\end{array}$ & 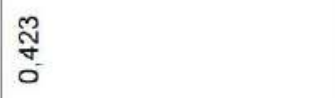 & $\begin{array}{l}\hat{\mathrm{p}} \\
\text { Oे }\end{array}$ & \\
\hline 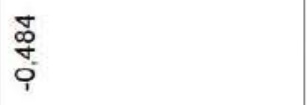 & $\frac{\sigma}{\dot{\sigma}}$ & 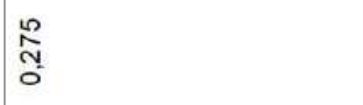 & Oొ \\
\hline$\frac{⿱ 艹}{0}$ & $\underset{\text { N }}{\stackrel{\delta}{0}}$ & $\frac{\pi}{5}$ & 总 \\
\hline 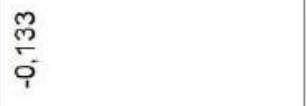 & $\begin{array}{l}\text { 옹 } \\
\text { 응 }\end{array}$ & $\begin{array}{l}\text { 㔛 } \\
\text { Oें }\end{array}$ & $\frac{N}{0}$ \\
\hline $\begin{array}{l}\text { fo } \\
\text { ô }\end{array}$ & $\begin{array}{l}\text { ¿े } \\
\text { : }\end{array}$ & $\frac{\bar{N}}{\bar{O}}$ & 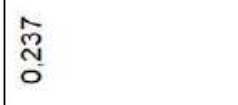 \\
\hline $\begin{array}{l}\text { 足 } \\
\text { o- }\end{array}$ & 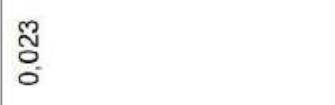 & $\hat{\ddot{o}}$ & 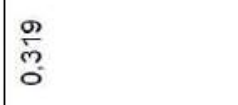 \\
\hline 음 & $\frac{q}{\frac{g}{0}}$ & ণั & 怘 \\
\hline$\frac{0}{i}$ & $\frac{\text { హ. }}{\circ}$ & 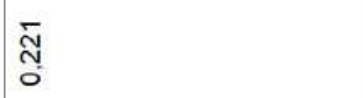 & 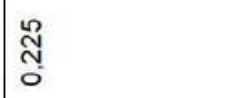 \\
\hline \begin{tabular}{l}
0 \\
\multirow{2}{0}{} \\
o.
\end{tabular} & $\stackrel{\infty}{\circ}$ & סु & $\frac{10}{0}$ \\
\hline 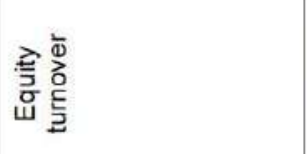 & 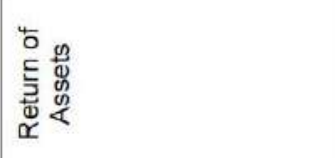 & 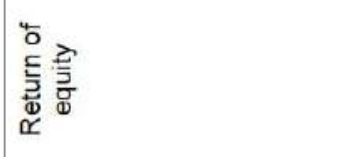 & 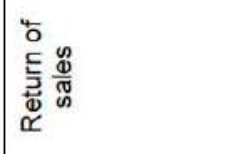 \\
\hline
\end{tabular}


It is necessary to pay attention to one interesting feature: an inverse connection between indicators (price, market and book value), turnover's indicators and indicators that characterize the financial stability of the company (except for factor of autonomy).

The conclusion is that net profit is the least significant indicator of profit within the framework of the value-oriented approach to decision-making.

\section{INFERENCE}

These results indicate that the traditional financial ratios in terms of the analysis of turnover and financial stability are not significant indicators of the value and price of business. At the same time, significant qualitative relationships are observed with indicators of profitability and capital structure (the factor of autonomy). This circumstance testifies to the need to develop a system of indicators that would take into account this feature and was more representative from the point of view of the value-oriented approach to making managerial decisions in the company.

\section{REFERENCES}

\section{Official Source}

Federal Law "On Appraisal Activities in the Russian Federation" of July 29, 1998 № 135-FZ (with amendment and add.).

\section{Books}

Damodaran A. Investment Valuation, John Wiley \& Sons, 2002.

Copeland T., Koller T., Murrin J. Valuation: Measuring and Managing the Value of Companies. $4^{\text {th }}$ ed. - New York: John Wiley \& Sons, Inc., 2005.

Kozyr Yu.V. The value of the company: evaluation and management decisions. Moscow: Alfa-Press, 2004.

Roche J. The Value of Nothing. Mastering Business Valuations. LES50NS Financial Publishing Limited, 2005.

Rumyantseva E.E. New economic encyclopedia. 2nd ed. - Moscow: Infra-M, 2006.

\section{Dissertations}

Varfolomeev E. V. Perfection of methods for assessing the impact of environmental and innovation activity on the company's market value: the abstract of the dis. ... Candidate of Economic Sciences: 08.00.05., Moscow, 2011; Staryuk P.Yu. The influence of corporate governance on the value of Russian companies: the empirical analysis: the abstract of the dis. ... candidate of economic sciences: 08.00.10., Moscow, 2008

\section{Monography}

Corporate management: issues of practice and evaluation of Russian companies / O.V. Bandalyuk, I.V. Berezinets, A.V. Buhvalov, D.L. Volkov, T.A. Garanina, Yu.B. Ilyina; Ed. A.V. Bukhvalova; Graduate School of Management, St. Petersburg State University. - SPb $\therefore$ Publishing house "Higher School of Management", monograph, 2012.

Received on 29-05-2018 Accepted on 24-09-2018

Published on 12-11-2018

DOI: https://doi.org/10.6000/1929-7092.2018.07.62

(C) 2018 Irina et al.; Licensee Lifescience Global.

This is an open access article licensed under the terms of the Creative Commons Attribution Non-Commercial License (http://creativecommons.org/licenses/by-nc/3.0/) which permits unrestricted, non-commercial use, distribution and reproduction in any medium, provided the work is properly cited. 